\title{
The Influence of variation the blade distance against the cocofibers and cocopeat percentage of the coconut fruit from Jambi Area
}

\author{
Emmistasega Subama,S.Si.,M.Sc ${ }^{1}$, Sepriyanto,S.T.,M.T ${ }^{1}$ \\ ${ }^{1}$ Mechanical Enginering Department, Politeknik Jambi, Jambi, Indonesia
}

\begin{abstract}
The influence of variationthe blade distance against the coco fiber and coco peat percentage of the coconut fruit from Jambi area has been done. The study aims to know the percentage of cocofiber and cocopeat produced based on the influence of variation the blade distance of decomposition machine starting from $5 \mathrm{~cm}, 10 \mathrm{~cm}$ and $15 \mathrm{~cm}$. Each round speed will operate for 2 minutes with 500 grams of raw material and use 10 decomposing blades. The results show that (1) distance of blade provides an influence on the value of the cocofiber and cocopeat produced (2) on the distance between the blade $5 \mathrm{~cm}$ obtained cocofiber as much as $30 \%$ and $62 \%$ of cocopeat raw materials. On the distance between the blade $10 \mathrm{~cm}$ obtained as much as $34 \%$ and cocofiber cocopeat $58 \%$ of raw materials, on the distance between the blade $15 \mathrm{~cm}$ obtained as many as $32 \%$ and cocofiber cocopeat $60 \%$ of the raw material (3) maximum of cocopeat cocofiber results on $10 \mathrm{~cm}$ distance between the blade..
\end{abstract}

\section{Introduction}

Coconut fruit has a high economic value ranging from the rough parts of the fibers to the delicate parts. Parts that are in the form of coarse fibers are usually traded as fuel, seat covers, woven ropes, brooms, mat material and much more. The potential of Jambi Province as a center for coconut plantations in 2012 reached 110,075 tons. Based on data from the Investment Coordinating Board (BKPM) coconut production in Jambi Province is increasing every year including in 2008 it reached 110,548 tons, in 2009 it reached 113,340 tons, in 2010 it reached 114,688 tons, in 2011 it reached 114,505 tons and in 2012 reached 110,075 tons. With so many coconut plantations in Jambi province, it is directly proportional to the waste of coconut fiber produced. This abundant coconut fiber waste has not been maximally utilized. Based on this, it is necessary to do an unused coconut fiber processing innovation by converting it to fiber (cocofiber) and powder (cocopeat) which has a high selling value by varying the distance of the decomposing blade. With this variation in blade distance, it is expected to produce the best quality coco fiber. Variation of blade distance start from $5 \mathrm{~cm}, 10 \mathrm{c}$, and $15 \mathrm{~cm}$ with $450 \mathrm{rpm}$ engine speed.

Research on this coconut fiber has been carried out. Coconut coir is used as a mixture of concrete, soundproofing, but not many have examined the appropriate technology for coconut fiber decomposition machines.In 2016, Djiwo and Setyawan has been researching the right technology machinery for coconut fiber in the UKM Sumber Rezeki Kediri Regency. The results obtained in the form of fiber length of $40 \mathrm{~cm}$ and short fibers of $19 \mathrm{~cm}$ and then cocopeat $28 \%$ on $400 \mathrm{rpm}$ the speed of the engine.

\section{Method}

The testing process begins by soaking the coconut husk for 1 hour and then draining it until there is no dripping water. After being dried, the coconut husk is beaten using an iron hammer with the aim that the coconut fiber is softened and the coconut fiber is inserted into the decomposing machine by varying the distance of the blade from $5 \mathrm{~cm}, 10 \mathrm{~cm}$ and $15 \mathrm{~cm}$. For more details about this testing process can be seen in the following research flow chart: 


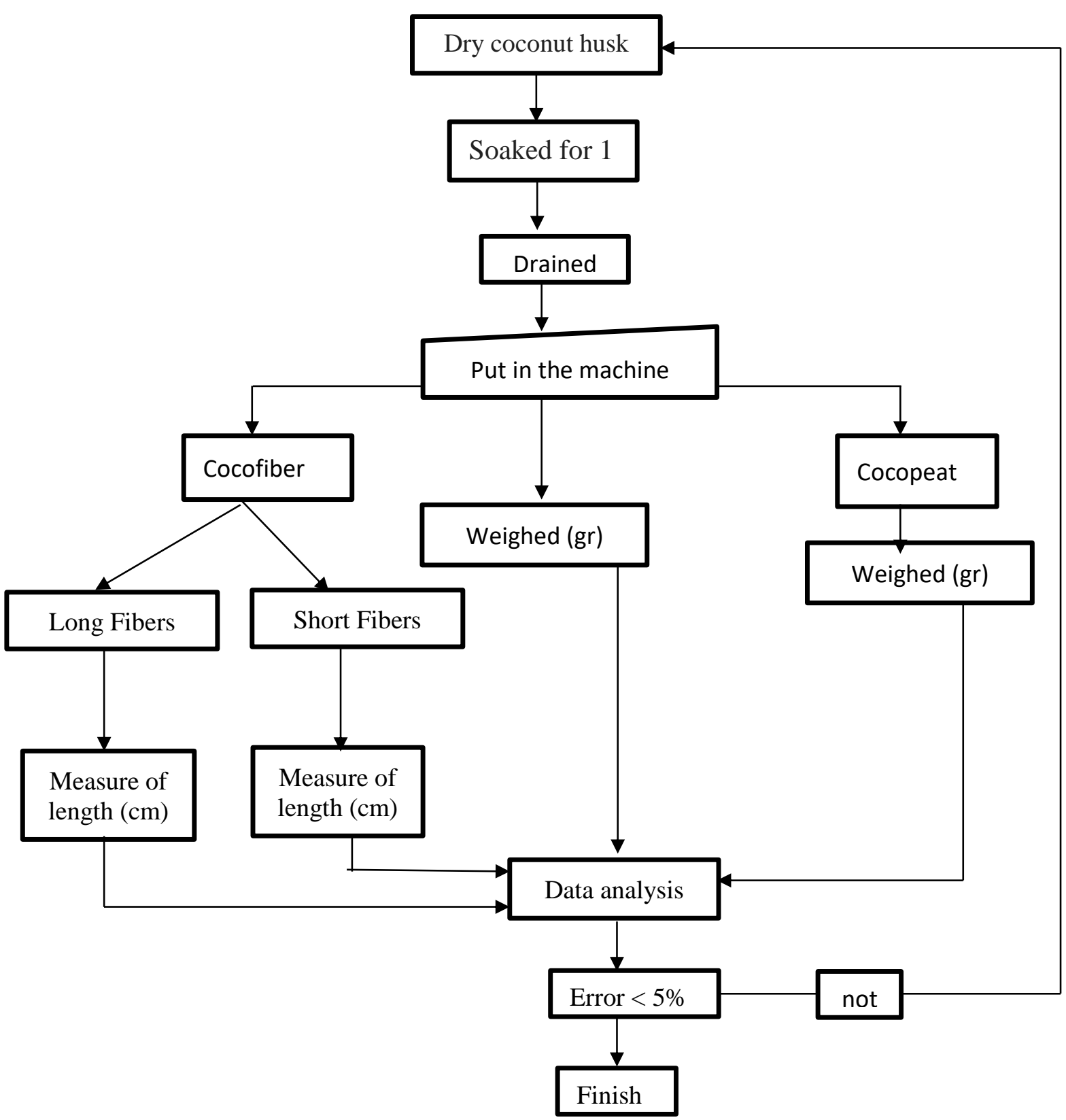

\section{Result and Discussion}

Tabel 1. Long Fibers And Short Fibers

\begin{tabular}{ccccc}
\hline $\begin{array}{c}\text { Distance of } \\
\text { Blade }(\mathrm{cm})\end{array}$ & Long fibers $(\mathrm{cm})$ & $\begin{array}{c}\text { Weight } \\
(\mathrm{gr})\end{array}$ & Short fibers $(\mathrm{cm})$ & $\begin{array}{c}\text { Weight } \\
(\mathrm{gr})\end{array}$ \\
\hline $\mathbf{5}$ & 30 & 55 & 11.5 & 5 \\
$\mathbf{1 0}$ & 28 & 50 & 11 & 9 \\
$\mathbf{1 5}$ & 28 & 47 & 10 & 5
\end{tabular}

Based on Tabel 1, the variation distance of blade give an effect to the amount of coco fiber produced. On the distance of blade $5 \mathrm{~cm}$, obtained long fibers an average length of $30 \mathrm{~cm}$ and short fibers an 
average length $11.5 \mathrm{~cm}$. On the distance of blade $10 \mathrm{~cm}$, obtained long fibers an average length of 28 $\mathrm{cm}$ and short fibers an average length $11 \mathrm{~cm}$ while on the distance of blade $15 \mathrm{~cm}$, obtained long fibers an average length of $28 \mathrm{~cm}$ and short fibers an average length $10 \mathrm{~cm}$. Maximum results are found in the distance of blade $5 \mathrm{~cm}$, namely fiber length $30 \mathrm{~cm}$ and short fiber $11.5 \mathrm{~cm}$. This result is far from that obtained by Djiwo and Setyawan (2016). The low results obtained may not be the maximum performance of the machines that have been made.

Tabel 2. Coco Fiber and Coco Peat

\begin{tabular}{cccc}
\hline $\begin{array}{c}\text { Distance of Blade } \\
(\mathrm{cm})\end{array}$ & $\begin{array}{c}\text { Raw of Material } \\
(\mathrm{gr})\end{array}$ & $\begin{array}{c}\text { Coco fibers } \\
(\mathrm{gr})\end{array}$ & $\begin{array}{c}\text { Coco peat } \\
(\mathrm{gr})\end{array}$ \\
\hline $\mathbf{5}$ & 500 & 60 & 225 \\
$\mathbf{1 0}$ & 500 & 61 & 128 \\
$\mathbf{1 5}$ & 500 & 52 & 218
\end{tabular}

Based on table 2, it was obtained at a distance of $5 \mathrm{~cm}$ blade the amount of cocofiber was $60 \mathrm{gr}$ and 225 gr coco peat. At a distance of $10 \mathrm{~cm}$ blade the amount of cocofiber was $61 \mathrm{gr}$ and $128 \mathrm{gr}$ coco peat while at a distance of $15 \mathrm{~cm}$ blade the amount of cocofiber was $52 \mathrm{gr}$ and $128 \mathrm{gr}$ coco peat. Percentage between long fibers, short fibers, coco fiber and coco peat show at picture 2 .

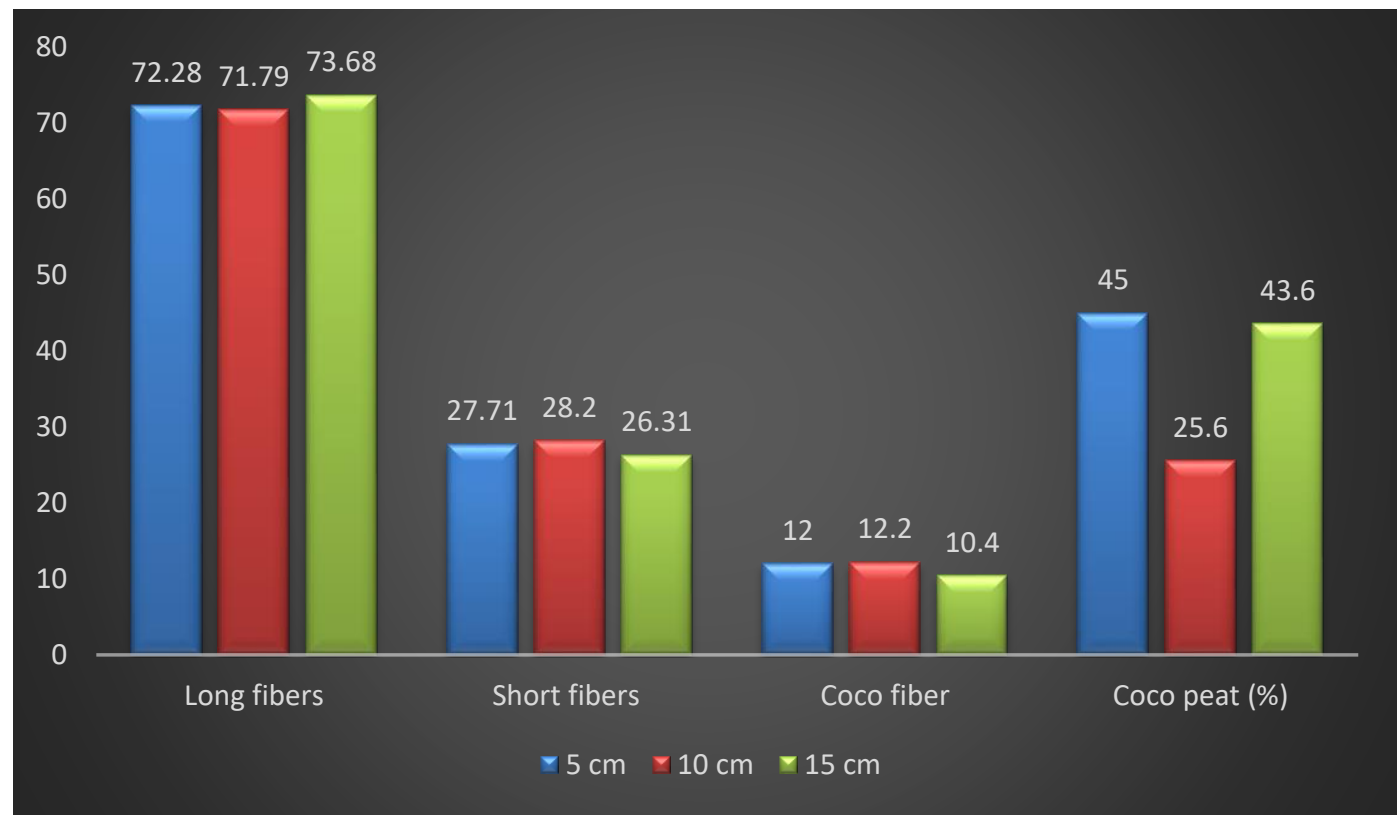

Picture 2. Graphic percentage between long fibers and short fibers

Based on Figure 2, the maximum coco fiber and coco peat results are obtained from the distance between the blades as far as $5 \mathrm{~cm}$. This comparison also shows that the distance between blades gives a significant effect on the yield of coco fiber and coco peat result.

\section{Conclusions}

Base on the research that has been done, the following conclusions are obtained:

1). The distance between the blades gives an influence on the amount of coco fiber and coco peat produced 
2). Long fibers and short fibers maximum length obtaned from the distance between of blades $5 \mathrm{~cm}$ which is equal $30 \mathrm{~cm}$ and $11.5 \mathrm{~cm}$.

3). Percentage of long fibers are maximum obtained from the distance between the blades $15 \mathrm{~cm}$ which is equal to , each of which is equal to $73.68 \%$ and percentage of short fibers are maximum obtained from the distance between the blades $10 \mathrm{~cm}$, each of which is equal to $28.2 \%$.

4). Percentage of coco fiber are maximum obtained from the distance between the blades $10 \mathrm{~cm}$, each of which is equal to $12.2 \%$ and coco peat are maximum obtained from the distance between the blade $5 \mathrm{~cm}$, each of which is equal $45 \%$.

\section{References}

[1] Djiwo, Soeparno and Setyawan, Eko Yohanes. 2016. Mesin Teknologi Tepat Guna Sabut Kelapa di UKM Sumber Rejeki Kabupaten Kediri. Prosiding Seminar dan Gelar Produk. UMM 17-18 Oktober hal 576-582, 2016.

[2] _ Jambi dalam angka 2010. Badan Pusat Statistik.2010 